\title{
Measurement of Gamma Emitting Radionuclides for Assessment, Environmental Hazards of Radiation in Rock and Soil Samples of Shabwah and Hadramout Regions, Yemen
}

\author{
Sherif S. Nafee ${ }^{1,2}$, Dheya Al-Othmany ${ }^{3}$, Safia H.Q. Hamidalddin' ${ }^{4}$ J.H. Al-Zahrani ${ }^{4}$, \\ W.R. Alharbi ${ }^{4}$, Hanan M. Barashed ${ }^{4}$ \\ ${ }^{1}$ Physics Department, Faculty of Science, King Abdulaziz University, Jeddah, Saudi Arabia \\ ${ }^{2}$ Physics Department, Faculty of Science, Alexandria University, Alexandria, Egypt \\ ${ }^{3}$ Nuclear Engineering Department, Faculty of Engineering, King Abdulaziz University, Jeddah, Saudi Arabia \\ ${ }^{4}$ Physics Department, Girls Faculty of Science, King Abdulaziz University, Jeddah, Saudi Arabia \\ Email: snafee@kau.edu.sa
}

How to cite this paper: Nafee, S.S., Al-Othmany, D., Hamidalddin, S.H.Q., AlZahrani, J.H., Alharbi, W.R. and Barashed, H.M. (2017) Measurement of Gamma Emitting Radionuclides for Assessment, Environmental Hazards of Radiation in Rock and Soil Samples of Shabwah and Hadramout Regions, Yemen. Journal of Geoscience and Environment Protection, 5, 66-75. https://doi.org/10.4236/gep.2017.55005

Received: April 10, 2017

Accepted: May 19, 2017

Published: May 22, 2017

Copyright (c) 2017 by authors and Scientific Research Publishing Inc. This work is licensed under the Creative Commons Attribution International License (CC BY 4.0).

http://creativecommons.org/licenses/by/4.0/

\section{(c) (i) Open Access}

\begin{abstract}
The natural radioactivity of ${ }^{226} \mathrm{Ra},{ }^{232} \mathrm{Th}$ and ${ }^{40} \mathrm{~K}$ and the fallout of ${ }^{137} \mathrm{Cs}$ in soils and granite rocks of two regions in Yemen (Shabwah and Hadramout) were measured by using gamma-ray spectrometry (HPGe) detector. The average values of the radionuclides ${ }^{226} \mathrm{Ra},{ }^{232} \mathrm{Th}$ and ${ }^{40} \mathrm{~K}$ in the soil samples are 14.34 , 25.78 and $566.05 \mathrm{~Bq} / \mathrm{kg}$ respectively. For rock samples, the average activity concentration for ${ }^{226} \mathrm{Ra},{ }^{232} \mathrm{Th}$ and ${ }^{40} \mathrm{~K}$ are 45,106 and $1235 \mathrm{~Bq} / \mathrm{kg}$ respectively. Low concentration values of ${ }^{137} \mathrm{Cs}$ in soil and rock samples under investigation, are not radiologically important. The radium equivalent activity (Raeq) and external hazard index (Hex) of all samples are less than the limits of 370 $\mathrm{Bq} \cdot \mathrm{kg}^{-1}$ and unity, respectively. The average values of total absorbed dose rate due to three primordial radionuclides in soil and rock samples are $46.5 \mathrm{nGy} / \mathrm{h}$ and $138.36 \mathrm{nGy} / \mathrm{h}$, respectively, where the absorbed average value of the granite is higher than the permitted limit. So, the local people must avoid using these granite samples as the interior decorative materials of dwelling without radioactivity control.
\end{abstract}

\section{Keywords}

Gamma Spectrometry, Annual Effective Dose, External Hazard Index

\section{Introduction}

The natural radioactivity of soil and rock samples is usually determined from the 
${ }^{226} \mathrm{Ra},{ }^{232} \mathrm{Th}$ and $40 \mathrm{~K}$ contents [1]. A significant amount of man-made radionuclides ${ }^{137} \mathrm{Cs}$, may also present in the environment as a result of testing of nuclear weapons in the atmosphere, accidents and the routine discharge of radionuclides from nuclear installations [2]. The specific level radiation in the crust varies from one region to another as the concentrations of these natural radioactive elements vary due to their non-uniform nature in soils and the types of rock from which the soil originates [3]. The knowledge of radiation levels in the environment is an important for assessing the effects of radiation exposure. So, the aim of the present study is to measure the natural radioactivity levels for estimating the radiogecal hazard indices in soils and granite rocks. This work can be used as a baseline guideline for assessing the exposure of the natural radiation in the study region, especially, in this area, the rocks and soils are used as building materials. The studied regions located in southwestern Yemen (Figure 1).

\section{Material and Methods}

\subsection{Samples Collection and Preparation}

A total of twenty soil sample at depths $(0-5,5-50,50-60$ and $60-70 \mathrm{~cm})$ underground and 6 granite rock samples were collected from different locations in Shabwah and Hadramout regions, Yemen, respectively. The sampling locations were chosen mostly in a wide area that we believe that it's representative of the important region. All soil samples collected from undisturbed sites located away from buildings, trees and roads to ensure that there was no influence of manmade structures and anthropogenic activities. The collected samples (soil and

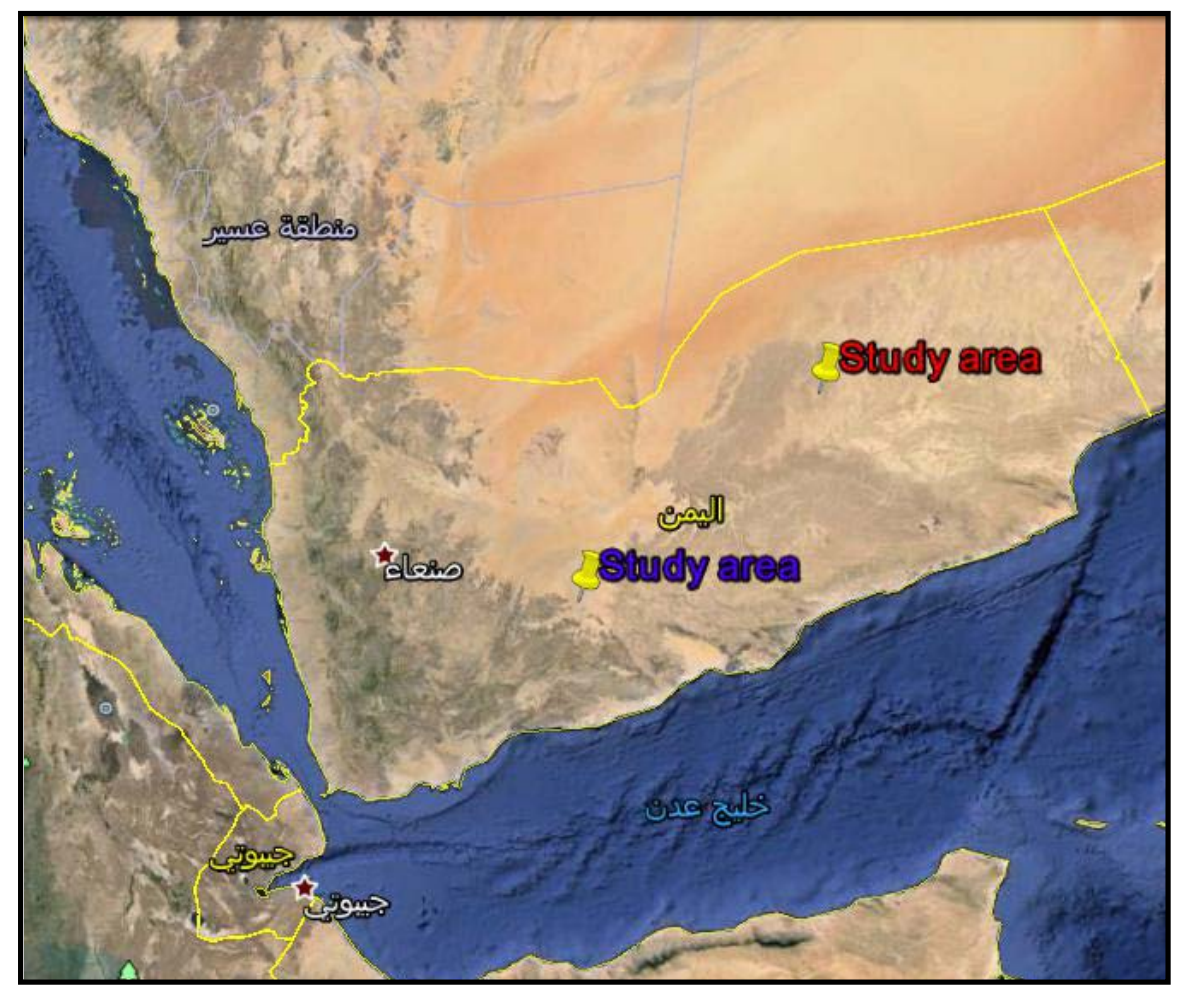

Figure 1. Location map of studying regions. 
granite) were first sundried and then oven dried at $110^{\circ} \mathrm{C}$ to constant weight. The samples were pulverized, homogenized and sieved through 1-mm mesh [4]. $500 \mathrm{gm}$ of each meshed sample was replaced in Marinelli beaker and then was stored for four weeks to reach the equilibrium state between radium and its decay products [5]. Radioactivity measurements were performed by using High purity Germanium (HPGe) detector (25\% relative efficiency). The measurement time of activity or background was 82800 seconds. The radioactivity concentration of ${ }^{226} \mathrm{Ra}$ was determined from the photopeaks of $295.09,351.87 \mathrm{Kev}\left({ }^{214} \mathrm{~Pb}\right)$, $609.31 \mathrm{Kev} \& 1120.27 \mathrm{keV} \& 1764.49 \mathrm{keV}\left({ }^{214} \mathrm{Bi}\right) .{ }^{232} \mathrm{Th}$ radioactivity was determined from $238.58 \mathrm{Kev}\left({ }^{212} \mathrm{~Pb}\right), 727.25 \mathrm{Kev}\left({ }^{212} \mathrm{Bi}\right)$ and $911.16 \mathrm{keV} \& 968.97 \mathrm{Kev}$ $\left({ }^{228} \mathrm{Ac}\right)$ while the ${ }^{40} \mathrm{~K}$ radioactivity was determined from $1460.8 \mathrm{Kev}$ and finally, ${ }^{137} \mathrm{Cs}$ was determined from the decay of ${ }^{40} \mathrm{Ar}$ and ${ }^{137} \mathrm{Ba}[4]$.

\subsection{Calculations}

The activity concentrations $(\mathrm{Bq} / \mathrm{kg})$ for the natural radionuclides in the measured samples were calculated after decay correction using the equation:

$$
\mathrm{A}_{\mathrm{c}}=\mathrm{Nc} /\left(m \beta \varepsilon_{a b s}\right)
$$

where $A_{c}$ is the activity concentration $(\mathrm{Bq} / \mathrm{kg})$ in the sample, $\mathrm{Nc}$ is the net area under the corresponding peak/second, $\mathrm{m}$ the dry weight sample mass $(\mathrm{kg}), \beta$ the branching ratio, and $\varepsilon_{a b s}$ is the detection absolute efficiency of a specific energy.

The radium equivalent activity is a very useful guideline in organization the safety standards in radiation protection for humans. The index calculated by the following relation [6].

$$
\mathrm{Ra}_{\mathrm{eq}}=\mathrm{A}_{\mathrm{Ra}}+\left(\mathrm{A}_{\mathrm{Th}} \times 1.43\right)+\left(\mathrm{A}_{\mathrm{K}} \times 0.077\right)
$$

where $A_{R a}, A_{T h}$ and $A_{K}$ are the activities of ${ }^{226} \mathrm{Ra},{ }^{232} \mathrm{Th}$ and ${ }^{40} \mathrm{~K}$, respectively, in $\mathrm{Bq} / \mathrm{kg}$, The formula is based on the assumption that $370 \mathrm{~Bq} / \mathrm{kg}$ of ${ }^{226} \mathrm{Ra}, 259$ $\mathrm{Bq} / \mathrm{kg}$ of ${ }^{232} \mathrm{Th}$ and $481 \mathrm{~Bq} / \mathrm{kg}$ of ${ }^{40} \mathrm{~K}$ produce the same gamma-ray dose rate [7].

The representative level index, $I_{\gamma}$ is used to estimate gamma radiation associated with the natural radionuclides in soil and calculated by the following equation [1]:

$$
I_{\gamma}=\frac{\mathrm{A}_{\mathrm{Ra}}}{300}+\frac{\mathrm{A}_{\mathrm{Th}}}{200}+\frac{\mathrm{A}_{\mathrm{K}}}{3000}
$$

where $A_{R a}, A_{T h}$ and $A_{K}$ are the activity concentrations of ${ }^{226} \mathrm{Ra},{ }^{232} \mathrm{Th}$ and ${ }^{40} \mathrm{~K}$, respectively in $\mathrm{Bq} / \mathrm{kg}$.

The external hazard index Hex can be calculated by the following equation [8]:

$$
\mathrm{H}_{\mathrm{ex}}=\mathrm{A}_{\mathrm{Ra}} / 370+\mathrm{A}_{\mathrm{Th}} / 259+\mathrm{A}_{\mathrm{K}} / 4810
$$

where $A_{R a}, A_{T h}$ and $A_{K}$ are the activity concentrations of ${ }^{226} \mathrm{Ra},{ }^{232} \mathrm{Th}$ and ${ }^{40} \mathrm{~K}$, respectively. The maximum value of $\mathrm{H}_{\mathrm{ex}}$ to be less than unity [8].

The absorbed gamma dose rates $\mathrm{D}(\mathrm{nGy} / \mathrm{h})$ in air at $1 \mathrm{~m}$ above the Earth's surface for the uniform distribution of radionuclides were calculated based on guidelines given by [8]: 


$$
D(n G / h)=0.427 \mathrm{~A}_{\mathrm{Ra}}+0.623 \mathrm{~A}_{\mathrm{Th}}+0.043 \mathrm{~A}_{\mathrm{K}}
$$

where, $A_{R a}, A_{T h}$ and $A_{K}$ are the activity concentrations $(B q / k g)$ of ${ }^{226} \mathrm{Ra},{ }^{232} \mathrm{Th}$ and ${ }^{40} \mathrm{~K}$, respectively.

The annual effective dose rate was calculated from the absorbed dose through the application of dose conversion factor of $0.7 \mathrm{~Sv} / \mathrm{Gy}$ with occupancy in the outdoor factor 0.2. [8]

$$
\mathrm{D}_{\text {eff }}(\mathrm{mSv} / \mathrm{y})=\operatorname{Dr}(\mathrm{nG} / \mathrm{h}) \times 8760 \mathrm{~h} \times 0.7(\mathrm{SvG} / \mathrm{y}) \times 0.2 \times 10^{-6}
$$

where $8,760 \mathrm{~h}$ is the number of hours in 1 year. $10^{-6}$ is a conversion factor of nano and Milli.

\section{Results and Discussion}

\subsection{Activity Concentrations}

The results of the measured values of activity concentrations for ${ }^{226} \mathrm{Ra},{ }^{232} \mathrm{Th},{ }^{40} \mathrm{~K}$ and ${ }^{137} \mathrm{Cs}$ obtained from the samples are presented in Table 1. From this table, the average values, concentrations of ${ }^{226} \mathrm{Ra},{ }^{232} \mathrm{Th}$, in soil and are less than the world average values [8]. ${ }^{40} \mathrm{~K}$ activity concentrations are in the range between 510.92 in the sample (S3) to $600.75 \mathrm{~Bq} / \mathrm{kg}$ in sample (S5) with an average value is

Table 1. Activity concentrations of natural radionuclides $\left({ }^{226} \mathrm{Ra},{ }^{232} \mathrm{Th}\right.$ and $\left.{ }^{40} \mathrm{~K}\right)$ and the

\begin{tabular}{|c|c|c|c|c|c|}
\hline \multirow{2}{*}{ Sample type } & \multirow{2}{*}{ Sample code } & \multicolumn{4}{|c|}{ Activity concentrations $(\mathrm{Bq} / \mathrm{kg})$} \\
\hline & & ${ }^{226} \mathrm{Ra}$ & ${ }^{232} \mathrm{Th}$ & ${ }^{40} \mathrm{~K}$ & ${ }^{137} \mathrm{Cs}$ \\
\hline \multirow{9}{*}{ Soil } & S1 & 15.37 & 28.29 & 546.35 & 0.83 \\
\hline & $\mathrm{S} 2$ & 14.93 & 25.90 & 560.05 & 0.17 \\
\hline & S3 & 14.38 & 22.85 & 510.92 & 1.56 \\
\hline & $\mathrm{S} 4$ & 13.90 & 24.56 & 595.18 & 0.01 \\
\hline & S5 & 13.10 & 24.07 & 600.75 & L.D.L \\
\hline & S6 & 13.97 & 29.03 & 583.05 & 0.25 \\
\hline & Range & $13.10-15.37$ & $22.85-29.03$ & $510.92-600.75$ & $0.01-1.56$ \\
\hline & Average & 14.28 & 25.78 & 566.05 & 0.56 \\
\hline & UNSCEAR 2000 & 30 & 35 & 400 & \\
\hline \multirow{9}{*}{$\begin{array}{c}\text { Granite rock } \\
\text { samples }\end{array}$} & G1 & 42.25 & 102.36 & 1480.26 & 1.15 \\
\hline & G2 & 37.36 & 83.93 & 1031.26 & 0.87 \\
\hline & G3 & 53.33 & 109.22 & 1058.50 & 0.75 \\
\hline & G4 & 45.17 & 103.89 & 1489.20 & 0.61 \\
\hline & G5 & 53.67 & 128.75 & 1076.01 & 0.57 \\
\hline & G6 & 38.21 & 104.71 & 1272.81 & 0.04 \\
\hline & Range & $37.36-53.67$ & $83.93-128.75$ & $1031.26-1489.2$ & $0.04-1.15$ \\
\hline & Average & 45 & 106 & 1235 & 0.67 \\
\hline & UNSCEAR 2000 & 50 & 50 & 500 & \\
\hline
\end{tabular}
fallout nuclide ${ }^{137} \mathrm{Cs}(\mathrm{Bq} / \mathrm{kg})$ in soil and granite samples. 
higher than the world average value [8]. Higher concentration values of ${ }^{40} \mathrm{~K}$ were obtained from the soil of Shabwah region, probably because the use of inorganic fertilizer in some locations and could also be attributed to the wearing away from the weathered surfaces of the potassium rich, igneous rocks which dominate a part of the geology of this region. The artificial radionuclide of ${ }^{137} \mathrm{Cs}$ concentrations in the soil samples are within the global atmospheric fallout and lower than the reported data for other countries. For granite samples, ${ }^{226} \mathrm{Ra},{ }^{232} \mathrm{Th}$ and ${ }^{40} \mathrm{~K}$ average concentrations are 45,106 , and $1235 \mathrm{~Bq} / \mathrm{kg}$ respectively. The average values of ${ }^{226} \mathrm{Ra}$ fall within the worldwide average values. While, ${ }^{232} \mathrm{Th}$ and ${ }^{40} \mathrm{~K}$ average values are twice the worldwide average values $(50,50$ and $500 \mathrm{~Bq} / \mathrm{kg}$ ) respectively [8]. The content of ${ }^{40} \mathrm{~K}$ in granite samples is the highest in all the sampling areas. So, it is the most abundant radionuclide of the total $\left({ }^{238} \mathrm{U}+{ }^{232} \mathrm{Th}\right.$ $+{ }^{40} \mathrm{~K}$ ), it is abundant about $89 \%$ followed by ${ }^{232} \mathrm{Th} 7.7 \%$. And finally ${ }^{226} \mathrm{Ra}$ is $3.3 \% .{ }^{137} \mathrm{Cs}$ is detected in all granite samples under investigation. The mean concentration of ${ }^{137} \mathrm{Cs}$ is $0.67 \mathrm{~Bq} / \mathrm{kg}$. These values are not radiologically important. Table 2 shows the comparison between the activity concentrations of soil samples with that of other countries of the World. The variations in the activity concentrations in the soil of the various locations of the world, depend upon the geological and geographical conditions of the area and the extent of fertilizer applied to the agricultural lands [8]. Table 3 , shows that, for granite samples results obtained in the present work are consistent with previous results and all results being within the range given in the report [8]. In general, the radioactivity in granite samples varied from one country to another [8]. Figure 2 shows a comparison between the obtained average values activity concentrations in soil and granite and the recommended values by UNSCEAR 2000 .

\subsection{Radiological Hazard Indices in Soil and Granite Rock Samples}

The computed results of the radiological hazard indices were listed in Table 4 .

Table 2. Comparison of natural radioactivity concentrations $(\mathrm{Bq} / \mathrm{kg})$ in the present soil samples with the reported values from different countries of the world.

\begin{tabular}{|c|c|c|c|c|}
\hline \multirow{2}{*}{ Country } & \multicolumn{3}{|c|}{ Average activity concentration (Bq/kg) } & \multirow{2}{*}{ References } \\
\hline & ${ }^{226} \mathrm{Ra}$ & ${ }^{232} \mathrm{Th}$ & ${ }^{40} \mathrm{~K}$ & \\
\hline Yemen & 14. 28 & 25.78 & 566.05 & Present study \\
\hline India & 45.68 & 17.11 & 1535.44 & [9] \\
\hline Saudi Arabia (Al-Qassim) & 9.3 & 12.3 & 535 & {$[10]$} \\
\hline Nigeria & 12.12 & 60.117 & 426.51 & [11] \\
\hline Malaysia & 57 & 68 & 427 & {$[12]$} \\
\hline Egypt & 16.4 & 7.1 & 102 & [13] \\
\hline Turkey & 21.0 & 23.5 & 363.5 & {$[14]$} \\
\hline Jordan & 57.7 & 18.1 & 138.1 & {$[15]$} \\
\hline World average & 30 & 35 & 400 & [8] \\
\hline
\end{tabular}


Table 3. Comparison of natural radioactivity concentration $(\mathrm{Bq} / \mathrm{kg})$ in the present granite samples with the reported values from different countries of the world.

\begin{tabular}{|c|c|c|c|c|}
\hline \multirow{2}{*}{ Country } & \multicolumn{3}{|c|}{ Average activity concentration $(\mathrm{Bq} / \mathrm{kg})$} & \multirow{2}{*}{ References } \\
\hline & ${ }^{226} \mathrm{Ra}$ & ${ }^{232} \mathrm{Th}$ & ${ }^{40} \mathrm{~K}$ & \\
\hline Yemen & 45 & 106 & 1235 & Present study \\
\hline India & 82 & 112 & 1908 & {$[16]$} \\
\hline Yemen & 54 & 127 & 1743 & {$[17]$} \\
\hline Spain & 84 & 42 & 1138 & {$[18]$} \\
\hline Saudi Arabia & 75 & 71 & 987 & [19] \\
\hline Egypt & 137 & 82 & 1082 & {$[20]$} \\
\hline Greek & 74 & 85 & 881 & {$[21]$} \\
\hline Turkey & 70 & 83 & 1234 & {$[22]$} \\
\hline Iran & 74 & 69 & 1130 & {$[23]$} \\
\hline Italy & 112 & 107 & 1063 & {$[24]$} \\
\hline Brazil & 45 & 106 & 1320 & {$[25]$} \\
\hline Japan & 43 & 72 & 1004 & {$[26]$} \\
\hline World average & 50 & 50 & 500 & UNSCEAR 2000 [8] \\
\hline
\end{tabular}

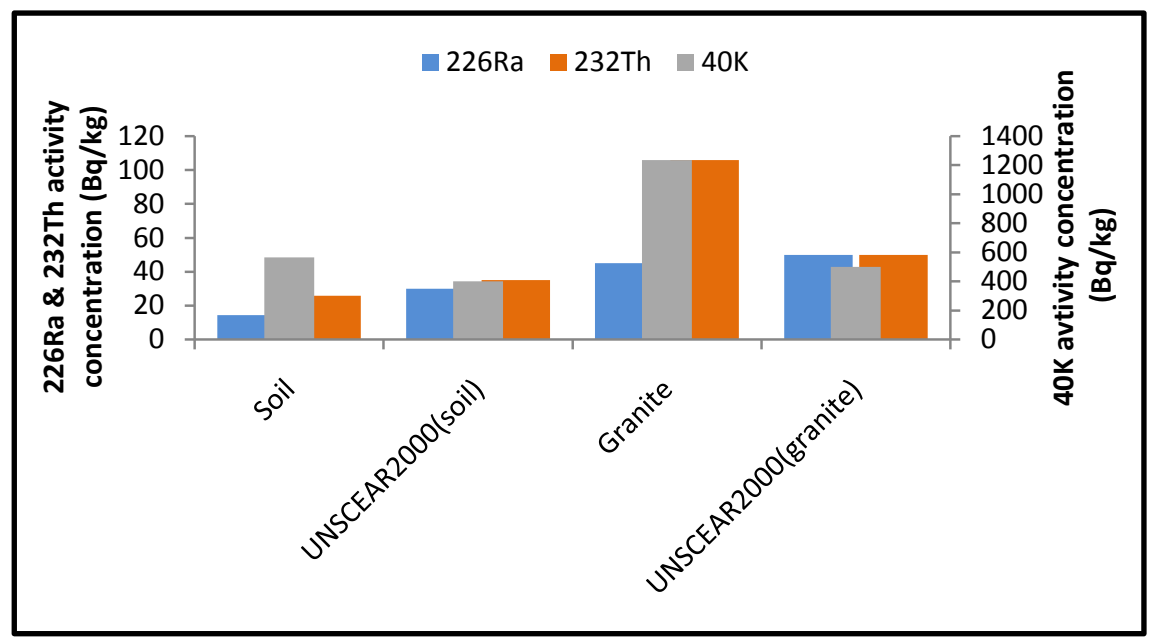

Figure 2. The activity concentrations of ${ }^{226} \mathrm{Ra},{ }^{232} \mathrm{Th}$ and ${ }^{40} \mathrm{~K}$ average values in soil and granite samples under investigation and UNSCEAR2000 values.

The values of $\mathrm{Ra}_{\mathrm{eq}} \mathrm{Bq} / \mathrm{kg}$ for soil and granite rock samples are lower than the allowed value of $370 \mathrm{~Bq} / \mathrm{kg}$ [8]. Representative level index $\left(I_{y}\right)$ average value is less than one, this means that the external radiation dose within the soil samples is less than the recommended dose of $1 \mathrm{~Bq} / \mathrm{kg}$ [8]. The $I_{Y}$ average values for granite rock is higher than $1 \mathrm{~Bq} / \mathrm{kg}$. External hazard index (Hex) for soil and granite samples are less than the limit value of unity. As can be seen in Table 4. The total absorbed dose rate calculated for Shabowah's soil, it less than the world average value of $57 \mathrm{nGy} / \mathrm{h}$. The presence of ${ }^{40} \mathrm{~K}$ in Shabwah's soil contributes a maximum of $52 \%$ to the total absorbed dose rate, followed by ${ }^{232} \mathrm{Th}$ of $35 \%$ and ${ }^{226} \mathrm{Ra}$ of $13 \%$, these contributions were illustrated in Figure 3. 
Table 4. Shows values of radium equivalent $\left(\mathrm{Ra}_{\mathrm{eq}}\right)$, level index $\left(I_{\gamma}\right)$ and external hazard $\left(\mathrm{H}_{\mathrm{ex}}\right)$ for soil samples (Shabwah) and granite rock samples (Hadramout), Yemen.

\begin{tabular}{|c|c|c|c|c|c|c|}
\hline \multirow{2}{*}{$\begin{array}{l}\text { Sample } \\
\text { type }\end{array}$} & \multirow{2}{*}{$\begin{array}{l}\text { Sample } \\
\text { code }\end{array}$} & \multicolumn{5}{|c|}{ Radiological Hazard } \\
\hline & & $\mathrm{Ra}_{\mathrm{eq}}(\mathrm{Bq} / \mathrm{kg})$ & Hex & $I_{Y}(\mathrm{~Bq} / \mathrm{kg})$ & $\mathrm{D}(\mathrm{nGy} / \mathrm{h})$ & $\mathrm{D}(\mathrm{eff}) \mathrm{mSv} / \mathrm{y}$ \\
\hline \multirow{8}{*}{ Soil } & S1 & 97.89 & 0.26 & 0.38 & 47.68 & 0.032 \\
\hline & S2 & 95.09 & 0.26 & 0.37 & 46.59 & 0.031 \\
\hline & S3 & 86.39 & 0.23 & 0.33 & 42.34 & 0.028 \\
\hline & S4 & 94.85 & 0.26 & 0.37 & 46.83 & 0.031 \\
\hline & S5 & 93.76 & 0.25 & 0.36 & 46.42 & 0.031 \\
\hline & S6 & 100.38 & 0.27 & 0.39 & 49.12 & 0.033 \\
\hline & Range & $86.39-100.38$ & $0.23-0.27$ & $0.33-0.39$ & $42.34-49.12$ & $0.028-0.033$ \\
\hline & Average & 94.73 & 0.26 & 0.36 & 46.50 & 0.031 \\
\hline \multirow{8}{*}{$\begin{array}{l}\text { Granite } \\
\text { rock }\end{array}$} & G1 & 302.61 & 0.82 & 1.15 & 145.47 & 0.097 \\
\hline & G2 & 236.79 & 0.64 & 0.89 & 112.58 & 0.075 \\
\hline & G3 & 291.02 & 0.79 & 1.08 & 136.33 & 0.091 \\
\hline & G4 & 308.40 & 0.83 & 1.17 & 148.05 & 0.099 \\
\hline & G5 & 320.64 & 0.87 & 1.18 & 149.40 & 0.1 \\
\hline & G6 & 285.95 & 0.77 & 1.08 & 136.28 & 0.091 \\
\hline & Range & $236.79-320.64$ & $0.64-0.87$ & $0.89-1.18$ & $112.58-149.40$ & $0.075-0.1$ \\
\hline & Average & 291.68 & 0.79 & 1.08 & 138.36 & 0.092 \\
\hline
\end{tabular}

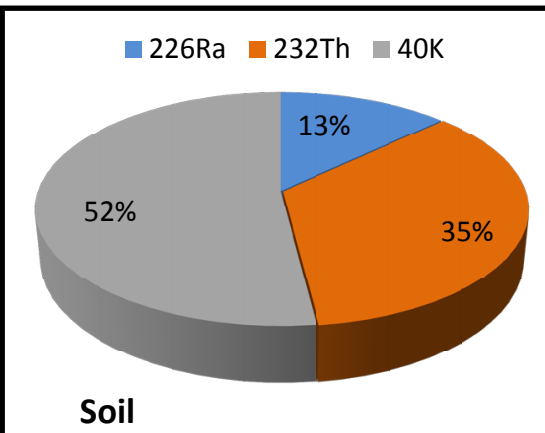

Figure 3. Comparison between percentage contributions absorbed dose of ${ }^{226} \mathrm{Ra},{ }^{232} \mathrm{Th}$ and ${ }^{40} \mathrm{~K}$ to total absorbed dose of soil and granite rock samples, Yemen.

The average value of annual effective dose equivalent of the study soil less than the world average value effective dose of $0.07 \mathrm{mSv} / \mathrm{y}$ [8]. According to these results of radiogecal hazard indices, one can indicate that the soil samples are safe and can be used as a construction material without posing any significant radiological threat to the population. As shown in Table 4, the average value of the absorbed dose rate of Hadramout region's granite samples is almost twice the world average value. So, the local people must avoid using these granite 
samples in the building construction, especially in the interior decorative materials of dwelling without radioactivity control. The average total effective dose rates $\left(D_{\text {eff }}\right)$ for granite samples is far lower than the $1.0 \mathrm{mSv} / \mathrm{y}$ recommended by [8]. This value is According to these results of radiogecal hazard indices, one can indicate that the soil samples are safe and can be used as a construction material without posing any significant radiological threat to the population. As shown in Table 4, the average value of the absorbed dose rate of Hadramout region's granite samples is almost twice the world average value. So, the local people must avoid using these granite samples in the building construction, especially in the interior decorative materials of dwelling without radioactivity control. The average total effective dose rates $\left(D_{\text {eff }}\right)$ for granite samples is far lower than the 1.0 $\mathrm{mSv} / \mathrm{y}$ recommended by [8].

\section{Conclusion}

The natural radioactivity levels of ${ }^{226} \mathrm{Ra},{ }^{232} \mathrm{Th}$ and ${ }^{40} \mathrm{~K}$ have been measured in soil and granite rock samples of two regions in Yemen using gamma ray spectroscopy. The mean activity concentrations of ${ }^{226} \mathrm{Ra},{ }^{232} \mathrm{Th}$ and ${ }^{40} \mathrm{~K}$ in soil are 14.28 , 25.78 and $566.05 \mathrm{~Bq} / \mathrm{kg}$, respectively, and for the granite rock samples the mean concentrations are 45,106 and $1235 \mathrm{~Bq} / \mathrm{kg}$, respectively. These values are compared with published values of other countries. The estimated hazard indices in soil samples are well lower than the recommended limit. Therefore, the present soil can be used as a construction or building materials without posing any radiological effect to the population. In granite rocks, the calculated dose rate was observed twice the world average value of $57 \mu \mathrm{Sv} / \mathrm{Y}$, which put the users of the granite rocks and people around the area on radiological hazard. This work has established background guideline on the natural radioactivity levels in the study area, which will provide a future reference for other studies.

\section{References}

[1] NEA-OECD (1979) Exposure to Radiation from Natural Radioactivity in Building Materials. Report by the Group of Experts of the OECD Nuclear Energy Agency (NEA), Paris.

[2] Kabir, K.A., Islam, S.M.A. and Rahman, M.M. (2009) Distribution of Radionuclides in Surface Soil and Bottom Sediment in the District of Jessore, Bangladesh and Evaluation of Radiation Hazard. Journal of Bangladesh Academy of Sciences, 33, $117-130$.

[3] Banerjee, K.S., Guin, R., Gutierrez-Villanueva, J.L., Charro, M.E. and Sengupta, D. (2012) Variation in U-238 and Th-232 Enrichment in U-Mineralized Zone and Geological Controls on Their Spatial Distribution, Singhbhum Shear Zone of India. Environmental Earth Sciences, 65, 2103-2110. https://doi.org/10.1007/s12665-011-1191-9

[4] IAEA (1989) International Atomic Energy Agency. Measurement of Radiation in Food and the Environment. Guidebook. Technical Report Series No. 295, IAEA, Vienna.

[5] Mollah, S., Rahman, N.M., Kodlus, M.A. and Husain, S.R. (1987) Measurement of High Natural Background Radiation Levels by TLD at Cox and Bazar Coastal Areas 
in Bangladesh. Radiation Protection Dosimetry, 18, 39-41.

[6] Beretka, J. and Mathew, P.J. (1985) Natural Radioactivity of Australian Building Industrial Materials, Industrial Wastes and By-Products. Health Physics, 48, 87-95. https://doi.org/10.1097/00004032-198501000-00007

[7] Stranden, E. (1976) Some Aspects on Radioactivity of Building Materials. Health Physics, 8, 167-173.

[8] UNSCEAR (2000) United Nations Scientific Committee on the Effects of Atomic Radiation Sources, Effects and Risks of Ionizing Radiation. United Nations, New York.

[9] Bala, P., Mehra, R. and Ramola, R.C. (2014) Distribution of Natural Radioactivity in Soil Samples and Radiological Hazards in Building Material of Una, Himachal Pradesh. Journal of Geochemical Exploration, 142, 11-15.

[10] El-Taher, A. and Alzahrani, J.H. (2015) Radioactivity Measurements and Radiation Dose Assessments in Soil of Al-Qassim Region, Saudi Arabia. Indian Journal of Pure \& Applied Physics (IJPAP), 52, 147-154.

[11] Innocent, A.J., Onimisi, M.Y. and Jonah, S.A. (2013) Evaluation of Naturally Occurring Radionuclide Materials in Soil Samples Collected from Some Mining Sites in Zamfara State, Nigeria. British Journal of Applied Science \& Technology, 3, 684692. https://doi.org/10.9734/BJAST/2013/3244

[12] Almayahi, B.A., Tajuddin, A.A. and Jaafar, M.S. (2012) Effect of the Natural Radioactivity Concentrations and $226 \mathrm{Ra} / 238 \mathrm{U}$ Disequilibrium on Cancer Diseases in Penang, Malaysia. Radiation Physics and Chemistry, 81, 1547-1558.

[13] El-Taher, A. (2011) Terrestrial Gamma Radioactivity Levels and Their Corresponding Extent Exposure of Environmental Samples from Wadi El Assuity Protective Area, Assuit, Upper Egypt. Radiation Protection Dosimetry, 145, 405-410. https://doi.org/10.1093/rpd/ncq425

[14] Baldık, R., Aytekin, H. and Erer, M. (2011) Radioactivity Measurements and Radiation Dose Assessments Due to Natural Radiation in Karabük (Turkey). Journal of Radioanalytical and Nuclear Chemistry, 289, 297-302. https://doi.org/10.1007/s10967-011-1077-Z

[15] Saleh, H. and Shayeb, M.A. (2014) Natural Radioactivity Distribution of Southern Part of Jordan (Ma'an) Soil. Annals of Nuclear Energy, 65, 184-189.

[16] Sonkawade, R.G., Kant, K., Muralithar, S., Kumar, R. and Ramola, R.C. (2008) Natural Radioactivity in Common Building Construction and Radiation Shielding Materials. Atmospheric Environment, 42, 2254-2259.

[17] Abd El-Mageed, I.A., El-Kamel, H.A., Abbady, A., et al. (2011) Assessment of Natural and Anthropogenic Radioactivity Levels in Rocks and Soils in the Environments of Juban Town in Yemen. Radiation Physics and Chemistry, 80, 710-715.

[18] Guillén, J., Tejado, J.J., Baeza, A., Corbacho, J.A. and Muñoz, J.G. (2014) Assessment of Radiological Hazard of Commercial Granites from Extremadura (Spain). Journal of Environmental Radioactivity, 132, 81-88.

[19] Aydarous, A.S., Zeghib, S. and Al-Dughmah, M. (2010) Measurements of Natural Radioactivity and the Resulting Radiation Doses from Commercial Granites. Radiation Protection Dosimetry, 142, 363-368. https://doi.org/10.1093/rpd/ncq216

[20] Amin, R.M. (2012) Gamma Radiation Measurements of Naturally Occurring Radioactive Samples from Commercial Egyptian Granites. Environmental Earth Sciences, 67, 771-775. https://doi.org/10.1007/s12665-012-1538-x

[21] Papadopoulos, A., Christofides, G., Koroneos, A., Papadopoulou, L., Papastefanou, C. and Stoulos, S. (2013) Natural Radioactivity and Radiation Index of the Major 
Platonic Bodies in Greece. Journal of Environmental Radioactivity, 124, 227-238.

[22] Cetin, E., Altinsoy, N. and Örgün, Y. (2012) Natural Radioactivity Levels of Granites Used in Turkey. Radiation Protection Dosimetry, 151, 299-305.

[23] Asgharizadeh, F., Abbasi, A., Hochaghani, O. and Gooya, E.S. (2011) Natural Radioactivity in Granite Stones Used as Building Materials in Iran. Radiation Protection Dosimetry, 149, 321-326.

[24] Marocchi, M., Righi, S., Bargossi, G.M. and Gasparotto, G. (2011) Natural Radionuclides Content and Radiological Hazard of Commercial Ornamental Stones: An Integrated Radiometric and Mineralogical-Petrographic Study. Radiation Measurements, 46, 538-545.

[25] Anjos, R.M.D., Ayub, J.J., Cid, A.S., Cardoso, R. and Lacerda, T. (2011) External Gamma-Ray Dose Rate and Radon Concentration in Indoor Environments Covered with Brazilian Granites. Journal of Environmental Radioactivity, 102, 1055-1061.

[26] Iwaoka, K., Hosoda, M., Tabe, H., Ishikawa, T., Tokonami, S. and Yonehara, H. (2013) Activity Concentration of Natural Radionuclides and Radon and Thoron Exhalation Rates in the Rocks Used as Decorative Wall Coverings in Japan. Health Physics, 104, 41-50.

Submit or recommend next manuscript to SCIRP and we will provide best service for you:

Accepting pre-submission inquiries through Email, Facebook, LinkedIn, Twitter, etc. A wide selection of journals (inclusive of 9 subjects, more than 200 journals)

Providing 24-hour high-quality service

User-friendly online submission system

Fair and swift peer-review system

Efficient typesetting and proofreading procedure

Display of the result of downloads and visits, as well as the number of cited articles Maximum dissemination of your research work

Submit your manuscript at: http://papersubmission.scirp.org/

Or contact gep@scirp.org 